\title{
Pendugaan Sebaran Kandungan Bauksit Dengan Metode Geolistrik Konfigurasi Schlumberger di Desa Sungai Batu Kabupaten Sanggau Kalimantan Barat
}

\author{
Hendro Tira ${ }^{(*)}$, Yudha Arman ${ }^{1 *}$, Yoga Satria Putra ${ }^{1 *}$
}

\author{
1) Program Studi Fisika, Fakultas Matematika dan Ilmu Pengetahuan Alam, \\ Universitas Tanjungpura, Pontianak \\ *Email : yudhaarman@gmail.com
}

\begin{abstract}
Abstrak
Telah dilakukan penelitian pendugaan sebaran bauksit di Desa Sungai Batu Kabupaten Sanggau dengan menggunakan metode geolistrik resistivitas. Pengambilan data menggunakan konfigurasi elektroda Schlumberger. Berdasarkan nilai resistivitasnya, model memperlihatkan potensi kandungan bauksit terletak pada koordinat $\mathrm{x}: 450.488,738-450.600,219$ dan $\mathrm{y}: 13.192,958-13.398,410, \mathrm{x}: 450.561,862-$ $450.642,555$ dan $\mathrm{y}: 13.205,977-13.426,689$, x:450.511,095-450.711,491 dan y:13.268,652-13.391,399, $\mathrm{x}: 450.489,110-450.631,580$ dan $\mathrm{y}: 13.181,137-13.368,025$. Selain mineral bauksit ada beberapa kandungan mineral lain yang bisa di interpretasikan antara lain adanya kandungan magnetit, batulempung, batu kerikil basah, aluvium dan sedimen pasir serta kandungan air tanah. Hal ini dipengaruhi oleh lokasi penyelidikan tepat berada di pinggiran sungai kapuas.
\end{abstract}

Kata kunci: Metode geolistrik, Konfigurasi Schlumberger, bauksit

\section{LatarBelakang}

Berdasarkan informasi awal yang didapat dari peta geologi pada daerah Sungai Batu, Kabupaten Sanggau ditemukan mineral arenit litos pejal sampai berlapis tebal, berselingan dengan batu lumpur dan litarenit berfelspar, serta batulanau. Dari hal tersebut dapat diduga daerah ini mengandung kadar alumina yang tinggi dan kadar besi yang rendah. Mineral inilah yang diduga sebagai bauksit yang bernilai ekonomis tinggi karena merupakan bahan utama industri pembuatan logam aluminium serta industri strategis lainnya. Salah satu contoh kegunaannya adalah sebagai campuran logam untuk membuat badan pesawat, peralatan rumah tangga serta kaleng aluminium.

Pendugaan sebaran bauksit dapat dilakukan dengan menggunakan metode geolistrik tahanan jenis. Metode geolistrik tahanan jenis merupakan metode yang menggunakan prinsip aliran arus listrik dalam menyelidiki struktur bawah permukaan bumi. Aliran arus listrik mengalir di dalam tanah melalui batuan dan sangat dipengaruhi oleh adanya air tanah dan garam yang terkandung di dalam batuan serta hadirnya mineral logam maupun panas yang tinggi. Oleh karena itu, metode geolistrik dapat digunakan pada penyelidikan hidrogeologi seperti penentuan aquifer dan identifikasi kandungan kontaminasi, penyelidikan mineral, survei arkeologi dan deteksi hot rocks pada penyelidikan panas bumi.
Pada penelitian ini, sebaran bauksit akan ditentukan menggunakan metode Geolistrik tahanan jenis konfigurasi Schlumberger. Metode ini dapat mengidentifikasi diskontinuitas lateral dan vertikal suatu anomali konduktif lokal. Metode ini dilakukan dengan menggunakan 2 (dua) elektroda arus dan 2 (dua) elektroda potensial. Arus diinjeksikan melalui elektroda arus dan pengukuran beda potensial dilakukan pada elektroda potensial (Telford, 1998). Pengolahan data dilakukan dengan menggunakan metode inversi memanfaatkan perangkat lunak Res2Dinv. Hasil pengolahan data akan ditampilkan dalam bentuk dua dimensi.

Tujuan penelitian ini adalah untuk menduga sebaran bauksit di Desa Sungai Batu, Kabupaten Sanggau berdasarkan metode geolistrik tahanan jenis. Dari hasil penelitian ini diharapkan dapat memberikan informasi cadangan bauksit di lokasi penelitian yaitu menduga ketebalan, kedalaman dan arah sebaran bauksit di daerah Sungai Batu, Kabupaten Sanggau sebelum dilanjutkan dengan proses eksploitasi.

\section{Landasan Teori}

\subsection{Survey Geolistrik Resistivitas}

Berdasarkan Sakka (2002) tujuan survey geolistrik tahanan jenis adalah mengetahui perbedaan tahanan jenis (resistivitas) bawah permukaan bumi dengan melakukan pengukuran di permukaan bumi. Pengukuran 
dengan konfigurasi Schlumberger menggunakan 4 elektroda, masing-masing 2 elektroda arus dan 2 elektroda potensial dimana telah dilakukan oleh (Azhar dan Handayani, 2004). Ilustrasi garis ekuipotensial yang terjadi akibat injeksi arus ditunjukkan pada dua titik arus yang berlawanan di permukaan bumi.

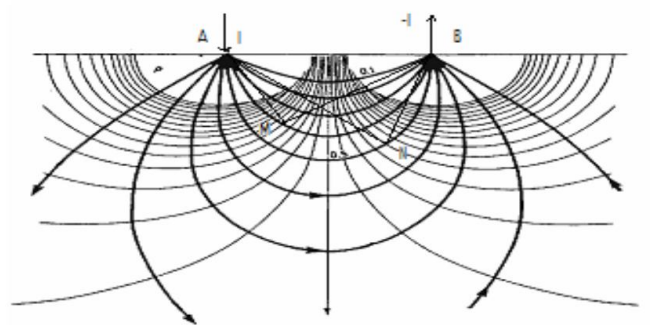

Gambar 1. Pola aliran arus dan bidang ekipotensial antara dua elektroda arus dengan polaritas berlawanan (Bahri, 2005)

Beda potensial yang terjadi antara $\mathrm{MN}$ yang disebabkan oleh injeksi arus pada $\mathrm{AB}$ adalah (Reynolds, 1997):

$\Delta V=V_{M}-V_{N}$

$\Delta V=\frac{I \rho}{2 \pi}\left[\left(\frac{1}{A M}-\frac{1}{B M}\right)-\left(\frac{1}{A N}-\frac{1}{B N}\right)\right]$

$\rho=2 \pi\left[\left(\frac{1}{A M}-\frac{1}{B M}\right)-\left(\frac{1}{A N}-\frac{1}{B N}\right)\right]$

Sehingga,

$\rho=k \frac{\Delta V}{I}$

dengan $\mathbf{I}$ arus dalam Ampere, $\boldsymbol{\Delta} \mathbf{V}$ beda potensial dalam Volt, $\boldsymbol{\rho}$ tahanan jenis dalam Ohm meter dan $\mathbf{k}$ faktor geometri elektroda dalam meter, maka (Reynolds, 1997):

$k=2 \pi\left[\left(\frac{1}{A M}-\frac{1}{B M}\right)-\left(\frac{1}{A N}-\frac{1}{B N}\right)\right]^{-1}$

dengan harga:

$\mathrm{MN}=\mathrm{a}$ (spasi elektroda potensial)

$\mathrm{AM}=\mathrm{NB}=\mathrm{n} \cdot \mathrm{a}$

$\mathrm{MB}=\mathrm{AN}=(\mathrm{n}+1) \cdot \mathrm{a}$

Untuk konfigurasi Schlumberger, harga $\mathrm{k}$ dapat dihitung menggunakan persamaan(Reynolds, 1997):

$$
\begin{aligned}
& \mathrm{k}=\mathrm{n} .(\mathrm{n}+1) \pi \mathrm{a} ; \\
& \mathrm{n}=1,2,3,4,5, \ldots .
\end{aligned}
$$

2.2.Metode Tahanan Jenis konfigurasi Schlumberger

Metoda tahanan jenis merupakan metode geofisika yang dipakai untuk pengukuran tahanan jenis semu suatu medium. Pengukuran dengan konfigurasi Schlumberger ini menggunakan 4 elektroda, masing-masing 2 elektroda arus dan 2 elektroda potensial (Gambar 2).

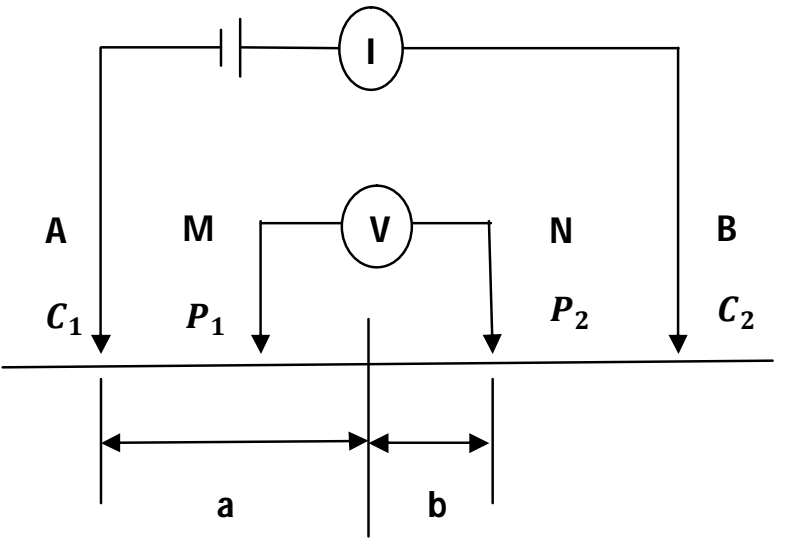

Gambar 2. Konfigurasi Schlumberger (Reynolds, 1997)

\section{Metode Pengambilan Data}

Pengambilan data geolistrik pada penelitian ini menggunakan konfigurasi Schlumberger. Pengukuran dilakukan sebanyak 4 lintasan secara horizontal dengan masingmasing lintasan sepanjang $240 \mathrm{~m}$. Pengukuran yang dilakukan menggunakan Ares resistivitymeter dilakukan secara otomatis tanpa harus mengatur konfigurasi elektroda sehingga dapat memperkecil kesalahan pengukuran. Data resistivitas hasil pengukuran tersimpan secara otomatis pada memori internal Ares resistivitymeter. Data ini dapat diambil melalui kabel serial (RS 232) to USB yang terhubung dengan note book. Data selanjutnya diolah menggunakan perangkat lunak Res2dinv. Hasil akhir dari pengolahan data menggunakan perangkat lunak Res2dinv adalah terbentuknya model resistivitas bawah permukaan yang dapat menjelaskan mengenai struktur tanah, jenis batuan dan mineral yang terdapat di bagian bawah permukaan daerah tempat dilakukannya kegiatan eksplorasi geolistrik.

\section{Hasil dan Pembahasan}

Adapun hasil interpretasi pengolahan data dijelaskan sebagai berikut.

\section{Lintasan I}

Titik pangkal dan ujung lintasan ini berada pada koordinat X:450.488,738-450.600,219 dan Y:13.192,958-13.398,410. Pada lintasan ini menghasilkan penampang resistivitas sebagaimana terlihat pada gambar berikut: 

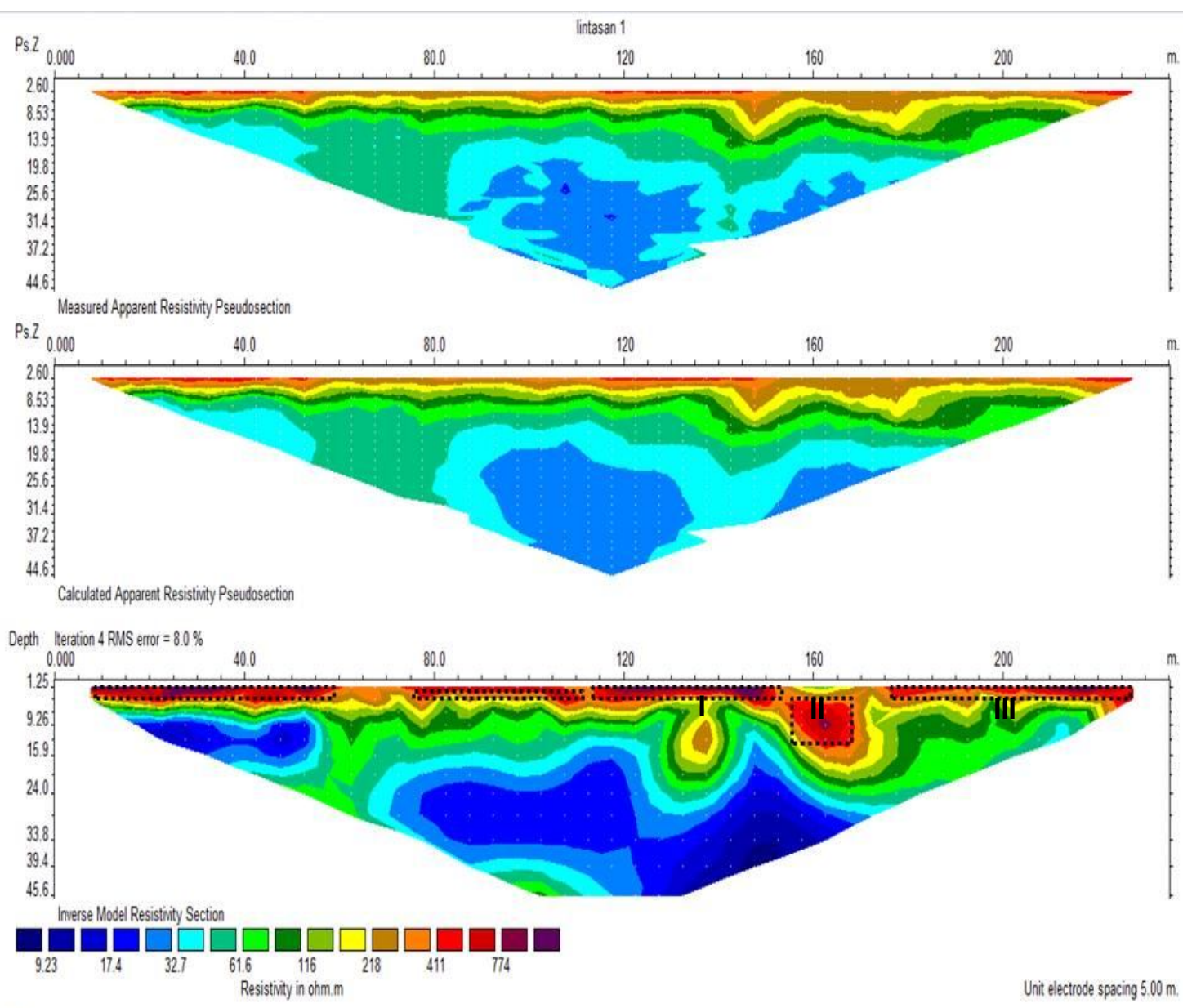

Gambar 3. Hasil pengolahan data Lintasan I menggunakan RES2DINV

Dari hasil pengolahan data terlihat bahwa terdapat sebaran nilai resistivitas yang beragam dari yang terkecil 9,23 $\Omega \mathrm{m}$ hingga $\pm 774 \Omega \mathrm{m}$. Adapun perbedaan nilai resistivitas tersebut dikarenakan oleh masing-masing sifat mineral yang terkandung di daerah penelitian itu sendiri, yang dimana lokasi ini didominasi oleh batuan lempung atau tanah lempung basah dan diduga pada bagian lapisan atas permukaan ada kandungan mineral bauksit. Mineral bauksit yang diduga terletak pada tiga titik dengan rentang nilai resistivitas sekitar 218-744 $\Omega \mathrm{m}$. Mineral bauksit yang pertama(I) diduga berada pada jarak $7 \mathrm{~m}$ - $150 \mathrm{~m}$ dari titik awal lintasan dengan kedalaman mulai dari 0-6 $\mathrm{m}$ dari permukaan. Pada titik kedua(II) terlihat ada sedikit intrusi sehingga pada arah sebarannya mengarah kedalam lapiasan yang berada pada jarak sekitar $155 \mathrm{~m}$ - $170 \mathrm{~m}$ dengan ketebalan berkisar 10 meter. Mineral bauksit yang ketiga (III) berada pada jarak $175 \mathrm{~m}$ - $225 \mathrm{~m}$ dari titik awal lintasan dengan kedalaman berkisar 0-5 $\mathrm{m}$ dari permukaan. Dari hasil pengolahan data ini juga terlihat banyak kandungan batuan sedimen pasir dan air tanah yaitu pada rentang nilai resistivitas $9,23 \Omega \mathrm{m}-116 \Omega \mathrm{m}$, hal ini dipengaruhi oleh lokasi pengambilan data terletak di penggiran sungai Kapuas.

\section{Lintasan II}

Titik pangkal dan ujung lintasan ini berada pada koordinat X:450.561,862-450.642,555 dan Y:13.205,977-13.426,689. Pada lintasan ini menghasilkan penampang resistivitas sebagaimana terlihat pada gambar berikut: 

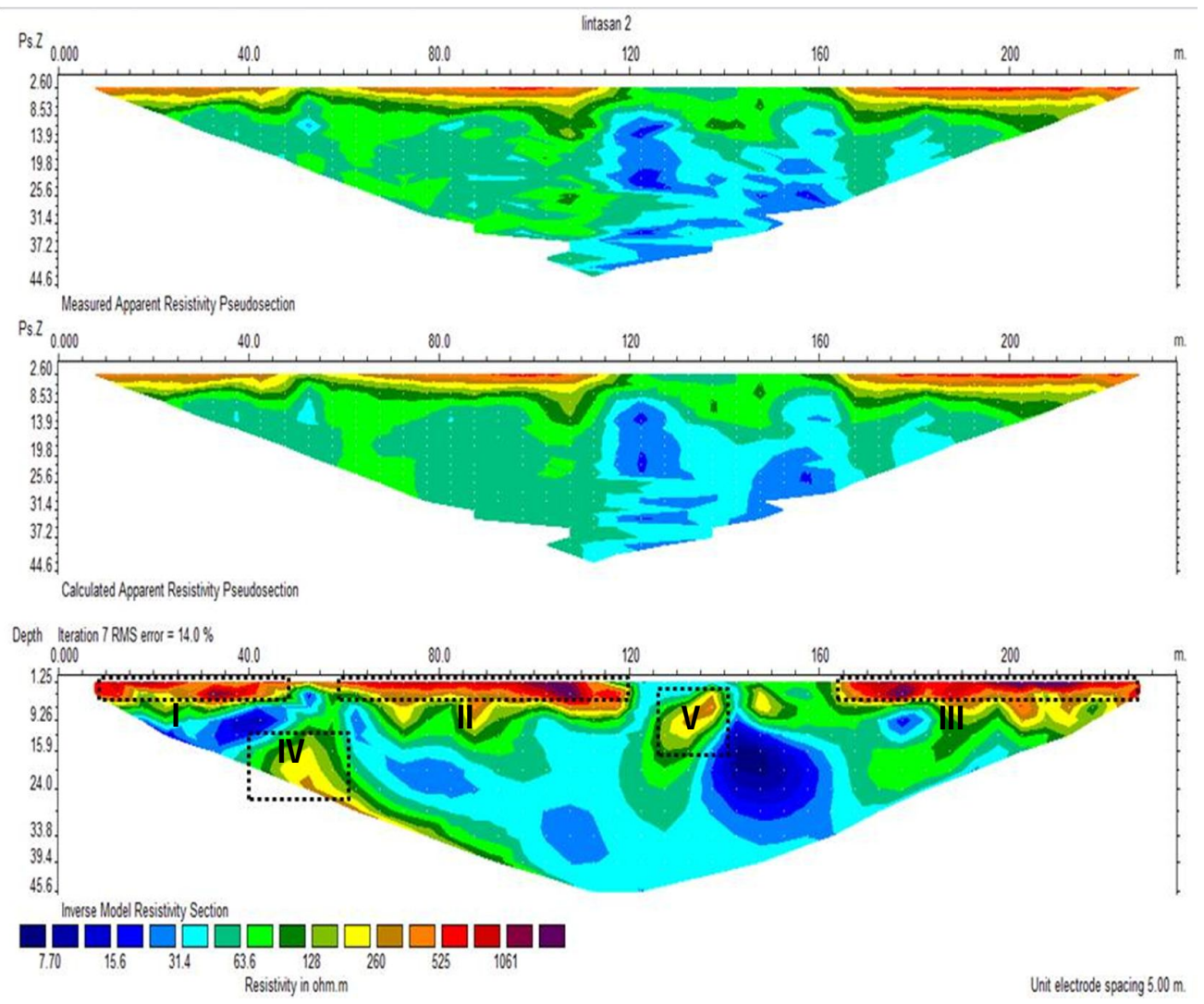

Gambar 4. Hasil pengolahan data Lintasan II menggunakan RES2DINV

Hasil pengolahan data lintasan kedua ini terlihat adanya proses intrusi batuan lempung serta batuan sedimen pasir yang tergerus oleh aliran air sehingga membentuk batuan kerikil basah, diduga adanya kandungan magnetit dan aluvium pada proses intrusi tersebut. Adapun yang diduga bauksit sesuai dengan nilai resistivitas yang ada pada tabel Telford terdapat tiga titik yaitu titik pertama pada jarak $7 \mathrm{~m}$ - 50 $\mathrm{m}$ dari titik awal lintasan dengan kedalaman berkisar dari 0 - $5 \mathrm{~m}$ dari permukaan. Titk kedua terdapat pada jarak $60 \mathrm{~m}-120 \mathrm{~m}$ dari titik awal lintasan dengan kedalaman 0 - $3 \mathrm{~m}$ dari permukaan dan titik ketiga terdapat pada jarak $165 \mathrm{~m}$ - $225 \mathrm{~m}$ dari titk awal lintasan dengan kedalaman berkisar 0 - $5 \mathrm{~m}$ dari permukaan. Rentang nilai resistivitas pada ketiga titik pendugaan tersebut berkisar antara $260-1061 \Omega \mathrm{m}$. Sedangkan kandungan magnetit dan aluvium pada titik ke (IV) dan ke (V) diduga terletak pada jarak $50 \mathrm{~m}-60 \mathrm{~m}$ dari titik awal lintasan dengan kedalaman mulai dari $12 \mathrm{~m}-24$ m dari permukaan dan pada jarak 125 m - 140 $m$ dari titik awal lintasan dengan kedalaman mulai dari $3 \mathrm{~m}-15 \mathrm{~m}$ dari permukaan dengan rentang nilai resistivitas sekitar $128-260 \Omega \mathrm{m}$.

\section{Lintasan III}

Titik pangkal dan ujung lintasan ini berada pada koordinat X:450.511,095-450.711,491 dan Y:13.268,652-13.391,399. Pada lintasan ini menghasilkan penampang resistivitas sebagaimana terlihat pada gambar berikut: 


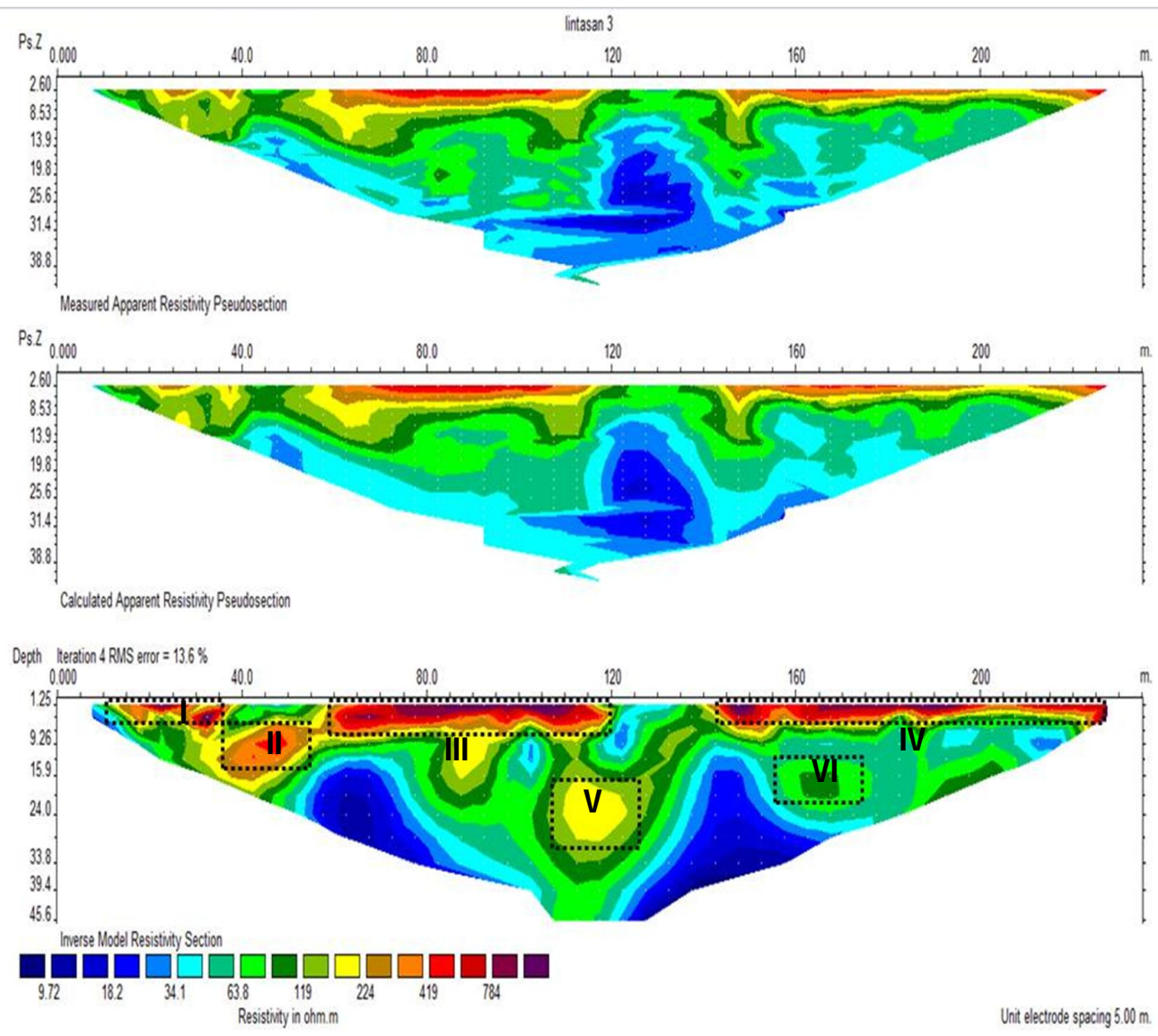

Gambar 5. Hasil pengolahan data Lintasan III menggunakan RES2DINV

Hasil pengolahan data lintasan ketiga terlihat ada beberapa lapisan yang terjadi terobosan, hal ini dipengaruhi oleh lokasi pada lintasan ketiga tampak kemiringan tanah dan terlihat ada cekungan pada permukaannya. Pada titik ke (V) ada terobosan, hal tersebut diduga mengandung magnetit dan alluvium yaitu pada jarak berkisar antara 105-125 m dari titik awal lintasan dengan kedalaman 16-30 m dari permukaan dan rentang nilai resistivitas tersebut 119-224 $\Omega \mathrm{m}$. Sedangkan titik ke (VI) pada jarak 157-177 m dari titik awal lintasan diduga terdapat batuan sedimen pasir dan lempung yang memiliki resistivitas rendah berkisar antara 63,8-119 $\Omega \mathrm{m}$ dengan kedalaman berkisar 12-20 m dari permukaan. Dari hasil pengolahan data yang diduga terdapat kandungan bauksit ada empat titik pendugaan. Titk pertama (I) yang diduga yaitu pada jarak antara 12 - $35 \mathrm{~m}$ dari titik awal lintasan dengan kedalaman berkisar $0-3 \mathrm{~m}$ dan rentang nilai resistivitas tersebut 224-784 $\Omega \mathrm{m}$. Titik kedua (II) pada jarak antara 35 - $55 \mathrm{~m}$ dari titik awal lintasan dengan kedalaman berkisar 6-12 m dari permukaan dan rentang nilai resistivitas tersebut 224-419 $\Omega \mathrm{m}$. Adapun titik ketiga (III) yang diduga mengandung bauksit pada jarak antara 60-120 m dari titik awal lintasan dengan kedalaman berkisar 0-6 $\mathrm{m}$ dari permukaan dan rentang nilai resistivitas tersebut $419-784 \Omega \mathrm{m}$. Sedangkan titik keempat (IV) yang diduga bauksit terbentang pada jarak 143-227 m dari titik awal lintasan dengan kedalaman berkisar 0-3 $\mathrm{m}$ dari permukaan dan rentang nilai resistivitas tersebut 224-784 $\Omega \mathrm{m}$.

\section{Lintasan IV}

Titik pangkal dan ujung lintasan ini berada pada koordinat X:450.489,110-450.631,580 dan Y:13.181,137-13.368,025. Pada lintasan ini menghasilkan penampang resistivitas sebagaimana terlihat pada gambar berikut: 

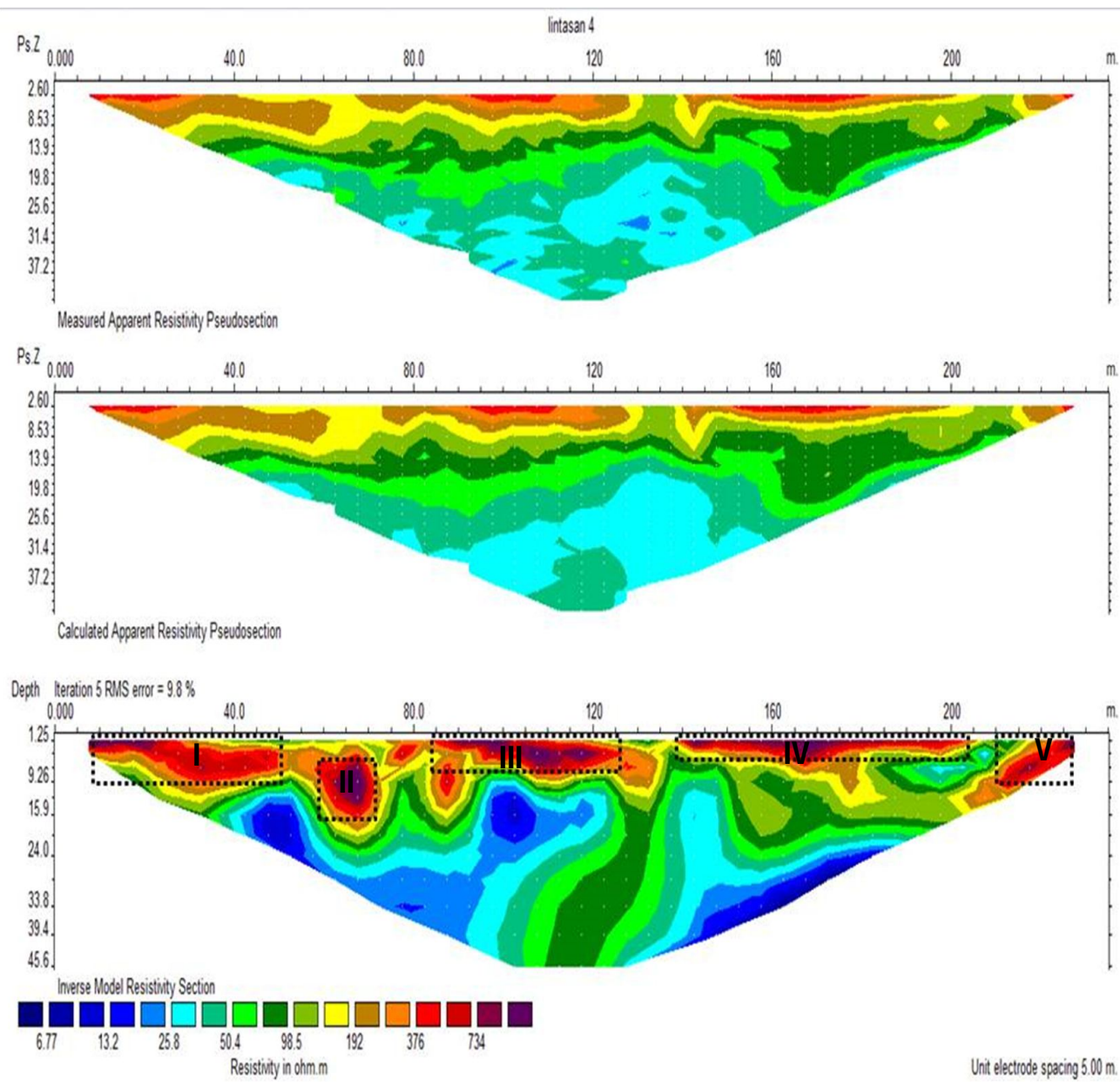

Gambar 6. Hasil pengolahan data Lintasan IV menggunakan RES2DINV

Hasil dari pengolahan data pada lintasan keempat terdapat sebaran nilai resistivitas mulai dari $6,77 \Omega \mathrm{m}$ hingga $734 \Omega \mathrm{m}$, diduga terdapatnya kandungan bauksit dengan rentang nilai resistivitas sekitar $376-734 \Omega \mathrm{m}$. Sebaran bauksit pada lintasan ini terletak di lima titik sebaran, titik pertama (I) berada pada jarak $7 \mathrm{~m}$ - $50 \mathrm{~m}$ dari titik awal lintasan dengan kedalaman mulai dari $0-7 \mathrm{~m}$ dari permukaan. Titik kedua (II) berada pada jarak $58 \mathrm{~m}-70 \mathrm{~m}$ dari titik awal lintasan dengan kedalaman mulai dari 4$16 \mathrm{~m}$ dari permukaan. Titik ketiga (III) berada pada jarak $85 \mathrm{~m}$ - $125 \mathrm{~m}$ dari titik awal lintasan dengan kedalaman mulai dari 0-5 $\mathrm{m}$ dari permukaan. Titik keempat (IV) berada pada jarak $140 \mathrm{~m}-200 \mathrm{~m}$ dari titik awal lintasan dengan kedalaman mulai dari 0-3 m dari permukaan. Titik kelima (V) berada pada jarak $210 \mathrm{~m}-227 \mathrm{~m}$ dari titik awal lintasan dengan kedalaman mulai dari 0-6 $\mathrm{m}$ dari permukaan.

\section{Kesimpulan}

\subsection{Kesimpulan}

Berdasarkan hasil analisis data geolistrik dan hasil interpretasi, maka dapat disimpulkan bahwa:

1. Dari hasil pengolahan data terlihat sebaran nilai resistivitas yang beragam mulai dari 6,77 $\Omega \mathrm{m}$ hingga $1.061 \Omega \mathrm{m}$ dikarenakan lokasi penelitian ini banyak terdapat beberapa mineral lain, beberapa mineral yang terinterpretasikan adalah mineral magnetit, batulempung, batu kerikil basah, alluvium dan sedimen pasir serta ada banyak struktur lapisan aliran air tanah. Ada banyaknya struktur lapisan aliran air tanah yang terlihat pada setiap lintasan dipengaruhi oleh lokasi penelitian berada dekat dengan aliran besar sungai kapuas.

2. Dari keseluruhan interpretasi data ke 4 Lintasan dengan bantuan tabel nilai resistivitas menunjukkan bahwa lokasi yang berpotensi diduga terdapatnya sebaran 
bauksit di lintasan I berada sepanjang lintasan dengan perkiraan kedalaman sebaran sebesar \pm 0-10 meter dari permukaan. Lintasan II juga diduga memiliki potensi bauksit sepanjang lintasan yang terbentang dengan perkiraan kedalaman sebaran sebesar \pm 0-5 meter dari permukaan. Lintasan III juga diduga memiliki potensi bauksit walaupun ada terlihat terobosan sebaran bauksitnya dan terbentang sepanjang lintasan dengan perkiraan kedalaman sebaran \pm 0-6 meter dari permukaan. Sedangkan lintasan IV juga diduga memiliki potensi sebaran bauksit dan terlihat sepanjang lintasan dengan perkiraan kedalaman sebaran \pm 0-8 meter dari permukaan.

\section{Pustaka}

Azhar dan Handayani, 2004. Penerapan Metode Geolistrik Konfigurasi Schlumberger untuk Penentuan Tahanan Jenis Batubara, Jurusan Geofísika Terapan ITB, Bandung.

Bahri, 2005. Hand Out Mata Kuliah Geofisika Lingkungan dengan topik Metoda Geolistrik Resistivitas, Fakultas Matematika dan Ilmu Pengetahuan Alam ITS, Surabaya.

Ibrahim, D. 2007. Survey Pendahuluan Bitumen Padat Di Kabupaten Sanggau dan Kabupaten Sekadau Provinsi Kalimantan Barat. Kelompok Program Penelitian Energi Fosil. Kalimantan Barat.

Loke, M.H. 2000. Electrical Imaging Surveys for Environmental and Engineering Studies: A Practical Guide to 2-D and 3-D Surveys. http:// www.geometrics.com.

Roynolds. J.M., 1997. An Introduction to Applied and Environmental Geophysics, John Wiley and sons Ltd, New York.

Sakka, 2002. Metoda Geolistrik Tahanan Jenis. Fakultas Matematika dan Ilmu Pengetahuan Alam - UNHAS, Makassar.

Telford, W.M., Geldart, L.P. dan Sheriff, R.E. 1998. Applied Geophysics. Second Edition. Cambridge University Press, New York. 